\title{
PENGEMBANGAN PERANGKAT PEMBELAJARAN AKUNTANSI DENGAN MENGGUNAKAN PENDEKATAN SAINTIFIK
}

\author{
Nanditia Widiasmara \\ e-mail:nanditia38@gmail.com \\ Lilik Sri Hariani \\ e-mail: liliksrihariani@unikama.ac.id \\ Affan Afian \\ e-mail: affanafian@unikama.ac.id
}

(Program Studi Pendidikan Ekonomi, Fakultas Ekonomika dan Bisnis, Universitas Kanjuruhan, Malang)

\begin{abstract}
This research is a research development of accounting learning tools in adjusting journal material to financial statements. The purpose of this study is to produce learning tools that can be used to support learning activities. The steps applied in this study include: (1) Identification of Potential and Problems; (2) Data Collection; (3) Product Design; (4) Design Validation; (5) Design Revision; (6) Product Trial; (7) Product Revision; and (8) Usage Trial. The subjects of this study were class X students at SMK PGRI 6 Malang, totaling 15 students. Data collection techniques in this study used observation, interviews, and questionnaires. The results of the validation of the learning tools that have been carried out by experts obtain feasible and effective criteria to be applied. The implication of this research development in accounting learning tools is that students become more active in learning activities because learning activities are more student-center.
\end{abstract}

Keywords : Accounting learning tool, Scientific Approach.

\begin{abstract}
Abstrak: Penelitian ini merupakan penelitian pengembangan perangkat pembelajaran akuntansi pada materi jurnal penyesuaian hingga laporan keuangan. Tujuan dari penelitian ini adalah untuk menghasilkan perangkat pembelajaran yang dapat digunakan untuk menunjang kegiatan pembelajaran. Langkah-langkah yang diterapkan dalam penelitian ini meliputi: (1) Identifikasi Potensi dan Masalah; (2) Pengumpulan Data; (3) Desain Produk; (4) Validasi Desain; (5) Revisi Desain; (6) Uji Coba Produk; (7) Revisi Produk; dan (8) Uji Coba Pemakaian. Subjek penelitian ini yaitu siswa kelas X di SMK PGRI 6 Malang yang berjumlah 15 siswa. Teknik Pengumpulan data dalam penelitian ini menggunakan observasi, wawancara, dan kuesioner. Hasil validasi perangkat pembelajaran yang telah dilakukan oleh para ahli memperoleh kriteria layak dan efektif untuk diterapkan. Implikasi dari penelitian pengembangan perangkat pembelajaran akuntansi ini yaitu siswa menjadi lebih aktif dalam kegiatan pembelajaran karena kegiatan belajar lebih berpusat pada siswa.
\end{abstract}

Kata kunci : Perangkat pembelajaran akuntansi, Pendekatan Saintifik 


\section{PENDAHULUAN}

Pendidikan merupakan salah satu kegiatan yang tidak lepas dari kehidupan manusia. Setiap zaman pasti mengalami perubahan ke arah yang lebih baik. Perubahan tersebut dilakukan agar inovasi dalam pembelajaran semakin meningkat sehingga menjadikan siswa semakin bersemangat dalam kegiatan pembelajaran. Perubahan di bidang pendidikan salah satunya adalah perubahan kurikulum. Perubahan dan pembaharuan kurikulum terjadi karena menyesuaikan dengan kebutuhan yang terdapat di masyarakat serta disesuaikan dengan perkembangan ilmu pengetahuan dan teknologi.

Implementasi Kurikulum 2013 dalam proses pembelajaran yaitu pembelajaran yang aktif. Sesuai Permendikbud No. 65 Tahun 2013 tentang Standar Proses bahwa Kurikulum 2013 menggunakan pendekatan ilmiah (saitifik) sebagai pendekatan pokok yang perlu diperkuat dengan pembelajaran berbasis penyingkapan, pembelajaran berbasis penelitian, dan pembelajaran berbasis proyek. Dengan adanya perubahan kurikulum tersebut menjadikan seorang guru harus beradaptasi dalam melaksanakan proses pembelajaran yaitu dalam penyusunan perangkat pembelajaran.

Guru diharapkan dapat mengembangkan perangkat pembelajaran serta menyusun secara lengkap dan sistematis agar pembelajaran dapat berjalan dengan efektif. Apriliasari (2015) menyatakan bahwa kurukulum 2013 menuntut siswa untuk mencari, mencoba, mengolah, mengkontrusi, dan menggunakan pengetahuannya melalui pengalaman belajar yang diberikan oleh guru, misalnya melatih siswa untuk bekerja memecahkan masalah aktual yang secara langsung berkaitan dengan kehidupan nyata yang ada di masyarakat. Salah satu pembelajaran yang berkaitan dengan kegiatan sehari-hari yang terjadi di masyarakat adalah pembelajaran ekonomi.

Salah satu bidang ilmu ekonomi yaitu akuntansi. Akuntansi adalah salah satu bidang ilmu yang tidak cukup dipelajari dari sisi teori saja tetapi harus dapat ditunjukkan dalam praktik nyata (Pujiati dalam Ananta, 2015). Akuntansi juga dijadikan mata pelajaran di sekolah menengah atas salah satunya di SMK PGRI 6 Malang, dimana SMK tersebut merupakan tempat peneliti melaksanakan Program Pengalaman Lapangan (PPL). Berdasarkan hasil observasi yang dilakukan, khususnya di kelas $X$ Akuntansi menunjukkan bahwa siswa masih kurang memperhatikan guru ketika guru menjelaskan di depan kelas. Siswa masih sibuk sendiri dengan aktifitasnya yaitu bermain handphone. Selain itu guru juga belum optimal dalam melakukan inovasi ketika melakukan pembelajaran dikelas. Melihat permasalah yang ada, maka perlu adanya pengembangan perangkat pembelajaran yang sesuai dengan kriteria pembelajaran di dalam kurikulum 2013.

Berdasarkan uraian tersebut maka rumusan permasalahan dalam penelitian ini adalah bagaimana mengembangkan perangkat pembelajaran akuntansi, bagaimana kelayakan perangkat pembelajaran yang dikembangkan, serta bagaimana keefektifan perangkat pembelajaran yang dikembangakan. Penelitian ini bertujuan untuk mengembangkan perangkat pembelajaran yang berbasis pendekatan saintifik pada materi jurnal penyesuaian hingga laporan keuangan

\section{TINJAUAN PUSTAKA}

Pengembangan menurut Sugiyono (2011:407) merupakan metode yang digunakan dalam penelitian dimana dalam penelitian tersebut menghasilkan atau memperbaharui produk tertentu serta menguji keefektifan produk yang dikembangkan. Terdapat 10 langkah dalam mengembangkan produk diantaranya: (1) Potensi dan Masalah; (2) Pengumpulan Data; (3) Desain Produk; (4) Validasi Desain; (5) Revisi Desain; (6) Uji Coba Produk; (7) Revisi Produk; (8) Uji Coba Pemakaian; (9) Revisi Produk; dan (10) Produksi Masal. Pengembangan yang dilakukan dalam penelitian ini yaitu pengembangan perangkat pembelajaran dimana terdiri atas Rencana Pelaksanaan Pembelajaran (RPP), modul, model pembelajaran, serta media pembelajaran. 
Seperti yang tercantum dalam Permendikbud No. 22 Tahun 2016 tentang Standar Proses Pendidikan Dasar dan Menengah mengenai Perencanaan Pembelajaran yang menyatakan bahwa Rencana Pelaksanaan Pembelajaran (RPP) merupakan rencana kegiatan pembelajaran tatap muka untuk satu pertemuan atau lebih. Sementara itu, menurut Akbar (2013:33-34) modul yaitu buku yang disusun dengan cakupan isi terbatas, sesuai dengan kurikulum atau silabus tertentu untuk satuan pendidikan tertentu pada tingkat dan semester tertentu., dimana ciri-ciri modul antara lain: (1) sumber materi ajar; (2) menjadi referensi baku untuk mata pelajaran tertentu; (3) disusun sistematis dan sederhana; dan (4) disertai petunjuk penggunaan. Selanjutnya menurut Akbar (2013: 49) tentang model pembelajaran yang menyatakan bahwa model pembelajaran merupakan pola dalam merancang pembelajaran, selain itu juga dapat didefinisikan sebagai langkah pembelajaran, dan perangkatnya untuk mencapai tujuan pembelajaran. Terdapat berbagai model pembelajaran, yaitu model pembelajaran group investigation, model pembelajaran role playing, model pembelajaran inkuiri, serta model pembelajaran cooperative learning.

Terakhir yaitu media pembelajaran, menurut Akbar (2013: 117) media merupakan alat bantu penyampaian pesan pembelajaran yang mengarahkan pada tujuan pembelajaran. Lalu menurut Sumanto (2012), fungsi media visual antara lain: (1) fungsi atensi, yakni menarik perhatian siswa untuk berkonsentrasi pada isi pembelajaran; (2) fungsi afeksi, yakni mencipatakan perasaan senang siswa; (3) fungsi kognisi, yakni alat bantu memahami dan mengingat informasi. Perangkat pembelajaran tersebut dikembangkan dengan menggunakan pendekatan saintifik, dimana pendekatan tersebut merupakan pendekatan pokok dalam penerapan Kurikulum 2013.

Sesuai dengan Permendikbud No. 65 tahun 2013 tentang Standar Proses, pendekatan saintifik dilaksanakan dengan langkah-langkah yaitu: (1) mengamati; (2) menanya; (3) mencoba; (4) mengasosiasi; dan (5) mengkomunikasikan. Pembelajaran dengan pendekatan saintifik dapat didefinisikan sebagai pembelajaran yang dirancang sedemikian rupa agar peserta didik memperoleh pengetahuan, keterampilan dan sikap melalui langkah-langkah mengamati, merumuskan pertanyaan, mengumpulkan data atau informasi dengan berbagai teknik seperti wawancara atau pengamatan, mengolah data atau informasi dan menarik kesimpulan serta mengkomunikasikan hasil analisis data.

Sementara materi yang akan dikembangkan merupakan materi akuntansi, dimana menurut Mursyidi (2010:17-18) yang menyatakan bahwa akuntansi merupakan proses pengidentifikasian data keuangan, memperoses pengolahan dan penganalisisan data yang relevan untuk diubah menjadi informasi yang dapat digunakan untuk pembuatan keputusan atau dapat diartikan sebagai proses pencatatan, penggolongan, peringkasan, pelaporan, dan penganalisisan data keuangan suatu organisasi. Dalam pengembangan perangkat pembelajarn ini, materi akuntansi yang dipilih meliputi jurnal penyesuaian, neraca lajur, serta laporan keuangan.

Menurut Hermawan (2006:94) yang menyatakan bahwa ayat jurnal penyesuaian (adjusting entry) merupakan ayat jurnal yang diperlukan pada setiap akhir periode akuntansi untuk memutakhirkan rekening dan untuk mengakui sepenuhnya pendapatan dan beban untuk periode bersangkutan berdasarkan akuntansi akrual. Sementara neraca lajur (worksheet) merupakan kertas kerja yang berisi semua data akuntansi yang akan digunakan untuk membuat laporan keuangan menurut Muawanah (2008:190). Lalu, laporan keuangan yang diperlukan melipuri laporan laba rugi, laporan perubahan ekuitas, dan neraca.

\section{METODE}


Penelitian yang digunakan dalam penelitian ini adalah penelitian pengembangan atau Research and Development. Penelitian ini menggunakan model pengembangan menurut Sugiyono. Model pengembangan menurut Sugiyono (2011:408) terdapat 10 langkah namun peneliti hanya menngunakan 8 langkah yaitu: (1) potensi dan masalah; (2) pengumpulan data; (3) desain produk; (4) validasi desain; (5) revisi desain; (6) uji coba produk; (7) revisi produk; dan (8) uji coba pemakaian. Produk yang dikembangkan dalam penelitian ini adalah perangkat pembelajaran yang terdiri atas Rencana Pelaksanaan Pembelajaran (RPP), modul, model pembelajaran, dan media pembelajaran. Sedangkan materi yang akan dikembangkan yaitu pada mata pelajaran akuntansi dasar materi jurnal penyesuaian, neraca lajur, dan laporan keuangan.

Subjek uji coba dalam penelitian ini adalah siswa kelas X Akuntansi SMK PGRI 6 Malang. Jumlah siswa kelas $\mathrm{X}$ Akuntansi tersebut yaitu 15 siswa dimana semuanya berjenis kelamin perempuan. Data penelitian diperoleh dari hasil validasi para ahli dan uji kompetensi siswa.validasi yang dinilai oleh para ahli menggunakan skala dengan skor 1-4. Setelah dilakukan validasi perangkat pembelajaran akan diujicobakan pada lapangan terbatas. Uji coba lapangan terbatas digunakan untuk melihat tingkat keefektifan perangkat pembelajaran yang dikembangkan.

\section{HASIL DAN PEMBAHASAN}

Berdasarkan hasil uji validitas yang dilakukan oleh para ahli yang telah dipilih, maka diperoleh hasil bahwa perangkat pembelajaran yang dikembangkan layak untuk diuji coba, dapat dilihat dalam Tabel 1 berikut ini:

Tabel 1 Hasil Validitas Rencana Pelaksanaan Pembelajaran (RPP)

\begin{tabular}{|l|l|l|}
\hline \multicolumn{1}{|c|}{ Aspek } & \multicolumn{1}{c|}{ Skor } & \multicolumn{1}{c|}{ Kriteria } \\
\hline RPP & $95 \%$ & Sangat valid, atau dapat digunakan tanpa revisi \\
\hline Modul (Validasi Guru) & 148 & Sangat valid, atau dapat digunakan tanpa revisi \\
\hline Modul (Validasi Dosen) & 146 & Sangat valid, atau dapat digunakan tanpa revisi \\
\hline Model & $97,2 \%$ & $\begin{array}{l}\text { Sangat valid, sangat efektif, dapat digunakan } \\
\text { tanpa revisi }\end{array}$ \\
\hline Media & $97 \%$ & $\begin{array}{l}\text { Sangat valid, sangat efektif atau dapat } \\
\text { digunakan tanpa revisi }\end{array}$ \\
\hline
\end{tabular}

Berdasarkan Tabel 1 dapat diketahui bahwa produk pembelajaran yang dikembangkan memiliki kriteria yang sangat baik, namun para ahli juga memberikan beberapa saran terhadap produk yang dikembangkan. Saran-saran tersebut akan dijadikan dasar untuk memperbaiki produk untuk diuji cobakan dilapangan yang lebih luas. Saran yang diberikan antara lain: 1) Penyampaian kepada siswa atau contoh yang digunakan upayakan lebih sederhana, 2) Jumlah latihan soal ditambah, 3) Daftar pustaka belum dicantumkan

Setelah dilakukan perbaikan, produk diuji coba pada siswa kelas X akuntansi PGRI 6 Malang dengan melibatkan 15 siswa. Selama proses pembelajaran berlangsung, kegiatan belajar berfokus pada siswa dikarenakan dalam Kurukulum 2013 proses pembelajarannya merupakan pembelajaran yang aktif dimana kegiatan pembelajaran berpusat pada siswa. Setelah siswa paham dengan materi yang diajarkan, peneliti memberikan tugas kepada siswa dimana tugas yang diberikan berupa media yang telah disiapkan yaitu puzzle amplop. Selain itu siswa juga diminta untuk mengerjakan evaluasi yang terdapat didalam modul. Hasil penilaian tugas siswa dapat dilihat dalam Tabel 2 berikut. 
Tabel 2 Hasil Nilai Tugas Siswa

\begin{tabular}{|l|c|}
\hline \multicolumn{1}{|c|}{ Nama Siswa } & Nilai \\
\hline Responden 1 & 76,15 \\
\hline Responden 2 & 91,25 \\
\hline Responden 3 & 89,25 \\
\hline Responden 4 & - \\
\hline Responden 5 & 92,15 \\
\hline Responden 6 & 93,75 \\
\hline Responden 7 & 79,65 \\
\hline Responden 8 & - \\
\hline Responden 9 & 91,25 \\
\hline Responden 10 & 81,62 \\
\hline Responden 11 12 & - \\
\hline Responden 12 & 83,15 \\
\hline Responden 13 & 80,15 \\
\hline Responden 14 & - \\
\hline Responden 15 & - \\
\hline
\end{tabular}

\section{Mengembangkan Produk Awal}

a. Potensi dan masalah

Berdasarkan hasil observasi yang dilakukan, terdapat beberapa siswa yang tidak mendengarkan dan memeperhatikan ketika guru menjelaskan materi di depan kelas. Maka perlu dikembangkan perangkat pembelajaran yang dapat meningkatkan minat belajar siswa.

b. Pengumpulan data

Pengumpulan data yang dilakukan dengan wawancara kepada guru dan siswa, memperoleh hasil bahwa dalam penyusunan perangkat pembelajaran beliau masih belum menggunakan pendekatan saintifik. Sehingga dari hasil wawancara yang dilakukan, peneliti membuat perangkat pembelajaran yang dibutuhkan sesuai dengan kebutuhan.

c. Desain produk

Adapun desain produk yang dibuat meliputi RPP, modul, serta media pembelajaran. Dimana RPP yang dibuat terdiri atas dua kali pertemuan dengan materi jurnal penyesuaian di pertemuan pertama dan materi neraca lajur serta laporan keuangan di pertemuan kedua. Media pembelajaran yang digunakan berupa amplop dimana didalamnya trerdapat potongan-potongan pertanyaan sehingga siswa harus menyusun potongan tersebut sebelum mengerjakan. Sedangkan pada pengembangan modul, isi modul meliputi: 1) Cover; 2) Rancangan modul yang mencakup pendahuluan, materi, serta evaluasi akhir; 3) Peta konsep yang bertujuan agar pembaca dapat memahami hubungan antar materi yang akan disampaikan; 4) Pendahuluan yang berisikan deskripsi tentang modul, prasyarat, pertunjuk penggunaan modul dan tujuan akhir yang ingin dicapai; 5) Materi; 6) Rangkuman sebagai ringkasan atas materi yang telah dijelaskan; 7) Latihan soal sebagai pengukur tingkat pemahaman siswa di setiap kegiatan pembelajaran yang berlangsung; 8) Evaluasi akhiryang berhubungan dengan pengumpulan informasi untuk menentukan tingkat pemahaman siswa terhadap materi yang telah diajarkan. 
d. Validasi desain

Desain produk yang telah dibuat kemudian divalidasi oleh ahli yang telah dipilih. Dimana ahli yang dipilih merupakan seorang dosen di Universitas Kanjuruhan Malang serta guru mata pelajaran yang bersangkutan. Hasil yang diperoleh dari validasi yaitu produk yang dikembangkan dapat digunakan tanpa adanya revisi.

e. Revisi desain

Meskipun dalam validasi desain produk yang dikembangkan bisa diterapkan tanpa adanya revisi, namun ada beberapa saran yang harus dipenuhi agar produk yang dikembangkan dapat diujikan tanpa adanya kekurangan. Saran yang pertama yaitu penambahan latihan soal. Saran yang kedua yaitu pencantuman daftar pustaka. Terakhir yaitu saran dalam menyampaikan materi usahakan menggunakan contoh yang lebih sederhana, sehingga siswa mudah memahami materi yang disampaikan.

f. Uji coba produk

Uji coba produk ini dilakukan pada empat siswa kelas X Akuntansi di SMK PGRI 6 Malang. Keempat siswa tersebut dipilih secara heterogen dengan tingkat kemampuan yang berbedabeda. Modul juga divalidasi oleh siswa, namun validasi yang dilakukan yaitu dengan cara melakukan uji kompetensi (tes). Tes yang peneliti berikan yaitu tes untuk materi jurnal penyesuaian. Hasil yang diperoleh dari uji kompetensi yang dilakukan yaitu keempat siswa mendapat rerata skor yang baik

g. Revisi produk

Setelah uji coba produk yang dilakukan, peneliti masih melakukan perbaikan perangkat pembelajaran karena masih terdapat kekurangan. Kekurangan tersebut yaitu pada modul yang dikembangkan karena terdapat bebrapa kata yang penulisannya salah seperti kurangnya huruf atau kata yang diulang dua kali sehingga memerlukan sedikit perbaikan

h. Uji coba pemakaian

Dalam pelaksanaan uji coba ini, siswa diberi modul yang telah dikembangkan. Selama proses pembelajaran berlangsung, kegiatan belajar berpusat pada siswa sehingga siswa menjadi aktif selama pembelajaran. Selain itu siswa juga menerapkan media yang telah dibuat oleh peneliti yaitu puzzle amplop pada pertemuan pertama. Pada saat penerapan media yang telah dibuat, siswa dikelompokkan menjadi 4 siswa dalam satu kelompok. Waktu yang diberikan untuk menyelesaikan tugas kelompok tersebut adalah 25 menit. Pada pertemuan kedua, siswa mempelajari materi neraca lajur dan laporan keuangan. Setelah pembahasan materi berakhir, siswa diberi tugas yaitu mengerjakan evaluasi akhir yang terdapat dalam modul. Hasil penilaian yang diperoleh menunjukkan rata-rata sangat baik yaitu sebesar 85,83

\section{Kelayakan Produk}

Hasil yang tertera pada Tabel 1 menunjukkan bahwa perangkat pembelajaran yang dibuat valid atau dapat digunakan tanpa adanya revisi. Perangkat pembelajaran dikatakan layak, alasannya yaitu hasil yang diperoleh termasuk dalam kriteria sangat valid yang berarti Rencana Pelaksanaan Pembelajaran yang telah di susun sudah mencerminkan pendekatan saintifik dalamnya dimana kegiatan pembelajarannya terfokus pada siswa. Tabel 1 juga menunjukkan hasil validasi yang telah dilakukan oleh para ahli mengenai modul yang dikembangkan. Aspek kelayakan dalam mengembangkan modul terdiri dari relevansi, keakuratan, kelengkapan sajian, sistematika sajian, kesesuaian sajian dengan tuntutan pembelajaran yang terpusat pada siswa, cara penyajian, 
kesesuaian bahasa dengan kaidah bahasa Indonesia yang baik dan benar, serta keterbacaan dan kekomunikatifan. Hasil validitas untuk model pembelajaran yang digunakan memperoleh skor 97,2\% yang berarti model pembelajaran layak untuk diterapkan dalam kegiatan pembelajaran. Terakhir adalah hasil validitas media pembelajaran yang memperoleh skor sebesar $97 \%$ yang berarti media pembelajaran layak untuk digunakan.

\section{Keefektifan Produk}

Efektivitas perangkat pembelajaran dilakukan dengan tes atau uji kompetensi kepada siswa. Uji kompetensi yang pertama dilakukan pada empat siswa kelas X Akuntansi yang telah dipilih secara acak. Hasil yang diperoleh pada tahap uji kompetensi yang pertama, yaitu diperolah rerata skor sebesar 81,2. Perolehan rerata tersebut termasuk kedalam kategori cukup valid untuk RPP. Sedangkan untuk keefektifan modul, hasil rerata tersebut termasuk kedalam kategori sangat valid. Terakhir yaitu keefektifan model pembelajaran yang digunakan, hasil yang diperoleh yaitu termasukkedalam ketegori sangat valid. Hal ini menyatakan bahwa perangkat yang dikembangkan efektif digunakan untuk kegiatan pembelajaran. Setelah dilakukan uji kompetensi yang pertama, uji kompetensi selanjutnya yaitu dengan memberikan tes kepada seluruh siswa kelas X Akuntansi. Tes yang diberikan yaitu siswa mengerjakan evaluasi akhir yang terdapat dalam modul. Evaluasi tersebut mencakup materi jurnal penyesuaian hingga laporan keuangan. Hasil yang diperoleh dari pemberian tes tersebut, siswa rata-rata sudah memperoleh nilai diatas kriteria ketuntasan minimum

\section{KESIMPULAN}

1. Pengembangan perangkat pembelajaran terdiri atas 8 tahap, yaitu: 1) Potensi dan masalah melalui observasi di kelas X Akuntansi di SMK PGRI 6 Malang; 2) Pengumpulan data dengan cara melakukan wawancara kepada guru mata pelajaran terkait; 3) Desain penelitian sesuai dengan hasil observasi dan wawancara yang telah dilakukan; 4) Validasi desain yang dilakukan oleh ahli yaitu 1 dosen Universitas Kanjuruhan Malang dan 1 guru SMK PGRI 6 Malang; 5) Revisi desain dilakukan setelah validasi desain, dimana terdapat beberapa saran yang harus direvisi; 6) Uji coba produk dilakukan pada empat siswa kelas X Akuntansi di SMK PGRI 6 Malang; 7) Revisi produk dilakukan karena ada beberapa kekurangan dalam produk perangkat pembelajaran; 8) Uji coba pemakaian dilaksanakan di kelas X Aknuntansi di SMK PGRI 6 Malang dengan jumlah 15 siswa.

2. Perangkat pembelajaran yang dikembangkan mendapat kriteria kelayakan antara lain untuk RPP sebesar 95\% . Modul mendapat skor sebesar 148 dan 146, masing-masing merupakan validasi dari guru dan dosen yang bersangkutan. Model dan media pembelajaran yang dikembangkan memperoleh skor masing-masing sebesar 97,2 dan 97\%, dimana semua perangkat tersebut termasuk dalam dengan kriteria sangat valid, sangat efektif dan dapat digunakan tanpa revisi.

3. Keefektifan perangkat pembelajaran yang dikembangkan dilihat dari hasil uji kompetensi yang diberikan kepada siswa. Hasil yang diperoleh dari uji kompetensi yang dilakukan yaitu 81,2 untuk uji kompetensi yang dilakukan pada lapangan terbatas yang diikuti oleh empat siswa. Hasil tersebut termasuk kedalam kriteria cukup valid, cukup efektif (cukup tuntas), dapat digunakan namun perlu perbaikan kecil untuk RPP, kategori sangat valid, atau dapat digunakan tanpa revisi untuk modul, dan sangat valid, sangat efektif, sangat tuntas, dapat digunakan tanpa perbaikan untuk model pembelajaran. Pada uji kompetensi lebih luas yang 
diikuti oleh seluruh siswa, hasil rerata yang diperoleh sebesar 85,83 sehingga dapat disimpulkan bahwa perangkat pembelajaran yang dikembangkan efektif

\section{DAFTAR PUSTAKA}

Akbar. Sa'dun. 2016. Instrumen Perangkat Pembelajaran. Bandung: Remaja Rosdakarya Ananta Sary, Devi. 2015. Pengembangan Bahan Ajar Berupa Modul Berbasis Scientific Approach pada Materi Metode Penilaian Persediaan pada Sistem Perpetual untuk Siswa Kelas XI SMK Negeri 2 Buduran Sidoarjo. Jurnal Pendidikan Akuntansi, 3 (2)

Ayu Apriliasari, Ratna. 2015. Pengembangan Modul Materi Jurnal Penyesuaian Perusahaan Dagang Berbasis Pendekatan Saintifik di Kelas XI SMK Negeri 1 Sooko Mojokerto. Jurnal Pendidikan Akuntansi, 3 (2)

Mursyidi. 2015. Akuntansi Dasar. Bogor: Ghalia Indonesia

Permendikbud No. 22 Tahun 2016

Permendikbud No. 65 Tahun 2013

Sugiyono. 2011. Metode Penelitian Kuantitatif Kualitatif dan R\&D. Bandung: Alfabeta 